AperTO - Archivio Istituzionale Open Access dell'Università di Torino

\title{
Anti-zika virus activity of polyoxometalates
}

\section{This is the author's manuscript}

Original Citation:

Availability:

This version is available http://hdl.handle.net/2318/1701118

since 2022-01-26T11:13:42Z

Published version:

DOI:10.1016/j.antiviral.2019.01.005

Terms of use:

Open Access

Anyone can freely access the full text of works made available as "Open Access". Works made available under a Creative Commons license can be used according to the terms and conditions of said license. Use of all other works requires consent of the right holder (author or publisher) if not exempted from copyright protection by the applicable law. 


\section{IIIS AperTO}

UNIVERSITÀ

DEGLI STUDI

DI TORINO

This is the author's final version of the contribution published as:

Rachele Francese, Andrea Civra, Massimo Rittà, Manuela Donalisio, Monica Argenziano, Roberta Cavalli, Ali S. Mougharbel, Ulrich Kortz, David Lembo. Anti-zika virus activity of polyoxometalates. Antiviral Res. 2019 Mar;163:29-33. doi: 10.1016/j.antiviral.2019.01.005.

The publisher's version is available at:

https://www.sciencedirect.com/science/article/pii/S0166354218306776

When citing, please refer to the published version.

Link to this full text:

http://hdl.handle.net/ 
2 Rachele Francese a , Andrea Civra a, Massimo Rittà a, Manuela Donalisio a, Monica Argenziano ${ }^{b}$,

3 Roberta Cavalli ${ }^{b}$, Ali S. Mougharbel ${ }^{c}$, Ulrich Kortz ${ }^{c^{*}}$, David Lembo ${ }^{a^{*}}$

$4 \quad{ }^{a}$ Dept. of Clinical and Biological Sciences; Laboratory of Molecular Virology and Antiviral Research;

5 University of Turin; S. Luigi Gonzaga Hospital; Orbassano (Turin), Italy.

$6 \quad{ }^{b}$ Dept. of Drug Science and Technology; Innovative Pharmaceutical and Cosmetic Technology and

7 Nanotechnology Group; University of Turin, Italy.

8 'Department of Life Sciences and Chemistry, Jacobs University, Campus Ring 1, 28759 Bremen,

9 Germany.

$10 *$ Corresponding authors

11 David Lembo, Email: david.lembo@unito.it

12 Ulrich Kortz, Email: u.kortz@jacobs-university.de

14 Keywords: zika virus, antivirals, polyoxometalates, entry inhibitor, flavivirus 
Abstract

Zika virus (ZIKV) is an emerging infectious viral pathogen associated with severe fetal cerebral anomalies and the paralytic Guillain-Barrè syndrome in adults. It was the cause of a recent global health crisis following its entrance into a naïve population in the Americas. Nowadays, no vaccine or specific antiviral against ZIKV is available. In this study, we identified three polyoxometales (POMs), the Anderson-Evans type $\left[\mathrm{TeW}_{6} \mathrm{O}_{24}\right]^{6-}\left(\mathrm{TeW}_{6}\right)$, and the Keggin-type $\left[\mathrm{TiW}_{11} \mathrm{CoO}_{40}\right]_{-}^{8-}\left(\mathrm{TiW}_{11} \mathrm{Co}\right)$, and $\left[\mathrm{Ti}_{2} \mathrm{PW}_{10} \mathrm{O}_{40}\right]^{7-}\left(\mathrm{Ti}_{2} \mathrm{PW}_{10}\right)$, that inhibit ZIKV infection with $\mathrm{EC}_{505}$ in the low micromolar range. $\mathrm{Ti}_{2} \mathrm{PW}_{10}$, the $\mathrm{POM}$ with the greater selectivity index (SI), was selected and the step of ZIKV replicative cycle putatively inhibited was investigated by specific antiviral assays. We demonstrated that $\mathrm{Ti}_{2} \mathrm{PW}_{10}$ targets the entry process of $\mathrm{ZIKV}$ infection and it is able to significantly reduce ZIKV progeny production. These results suggest that the polyanion $\mathrm{Ti}_{2} \mathrm{PW}_{10}$ could be a good starting point to develop an effective therapeutic to treat ZIKV infection. 
ZIKV is an enveloped positive-strand RNA virus belonging to the Flaviviridae family and mostly transmitted by Aedes aegypti mosquitos. ${ }^{1}$ Sexual, vertical and blood transmissions have also been reported. ${ }^{2-4}$ In symptomatic individuals (around $18 \%$ of cases), ZIKV causes a mild illness characterized by fever, rash, headache, conjunctivitis, joint and muscle pain; ${ }^{5}$ this clinical presentation is similar to that of other arbovirus infections, such as chikungunya and dengue virus. However, unlike other flavivirus, ZIKV is associated to two main neurological complications: the Guillain-Barré Syndrome in adults and the now termed Zika Congenital Syndrome (CSZ), a variety of neurological impairments in fetus and infants of women infected during pregnancy. The main congenital manifestations, developed in nearly one third of these newborns, are severe microcephaly, resulting in a partially collapsed skull, intracranial calcifications, eyes abnormalities, redundant scalp skin, arthrogryposis and clubfoot. ${ }^{3,6,7,8}$ Specifically, the risk of microcephaly, with a catastrophic impact on the socioeconomic status of affected families, was reported to be $1-13 \%$ during the first trimester and negligible during second and third trimesters. ${ }^{9}$

ZIKV can be classified into two lineages (African and Asian) and three genotypes (West African, East African, and Asian), differing in pathogenicity and virulence. The Asian-lineage ZIKV, responsible for the latest epidemics (on Yap Island and Micronesia in 2007, in French Polinesya in 2013 and in the Americas in 2016), is considered to be less virulent than the African one, because of the lower infection rate, the lower viral production, the poor induction of early cell death and the lower immuno-stimulation in different models. These characteristics allow the virus to cause a prolonged infection within the central nervous system of fetus that could be the cause of its association with neurological impairments. On the contrary, the African lineage-ZIKV can result in a more acute infection. ${ }^{10-14}$

The last major epidemic in the Americas, in 2016, counted 177614 confirmed ZIKV cases and 2552 cases of CSZ at the end of the year, driving the World Health Organization to declare a public health emergency of international concern. ${ }^{15,16}$ Since then, great efforts have been carried out, but nowadays still no vaccine or specific antiviral against ZIKV is available. ${ }^{17,18}$ The best way to prevent ZIKV infection is to avoid mosquito bites and the treatment of infected patients is palliative, involving analgesics and antipyretics. In this context, ZIKV infection presents a huge challenge to the global health system and the search for efficient antivirals is absolutely necessary. To this aim, we investigated in vitro the anti-ZIKV activity of a minilibrary of three polyoxometalates (POMs). POMs are 
discrete, anionic metal-oxo complexes of early $d$ block metal ions in high oxidation states (e.g. $\mathrm{W}^{\mathrm{VI}}, \mathrm{Mo}^{\mathrm{VI}}, \mathrm{V}^{\mathrm{V}}$ ) with a very large structural and compositional variety and a multitude of associated physicochemical properties. ${ }^{19-21}$ POMs are usually synthesized in aqueous acidic media, but some selected species are also stable at $\mathrm{pH}$ 7-8. In fact, POMs have been investigated for many years as potentially useful agents in medicine, mainly for their antiviral, antitumoral, and antibacterial properties. ${ }^{22-28}$ Here, we decided to investigate the following three solution-stable POMs, the Anderson-Evans type $\left[\mathrm{TeW}_{6} \mathrm{O}_{24}\right]^{6-}\left(\mathrm{TeW}_{6}\right)^{29}$ and the Keggin-type $\left[\mathrm{TiW}_{11} \mathrm{CoO}_{40}\right]^{8-}{ }_{-}\left(\mathrm{TiW}_{11} \mathrm{Co}\right),{ }^{30}$ and $\left[\mathrm{Ti}_{2} \mathrm{PW}_{10} \mathrm{O}_{40}\right]^{7-}\left(\mathrm{Ti}_{2} \mathrm{PW}_{10}\right),{ }^{31}$ which were all synthesized according to the published procedures. The size of all three polyanions is in the range of $1 \mathrm{~nm}$ diameter. The purity ( $\geq 95 \%$ ) of the compounds was confirmed by NMR and IR (Data available in Supplementary info). Some of these POMs have already been used in biological studies. For instance, $\mathbf{T i}_{\mathbf{2}} \mathbf{P} \mathbf{W}_{\mathbf{1 0}}$ showed interesting results in the inhibition of acetylcholinesterase activity while maintaining low toxicity levels. ${ }^{32}$ On the other hand, TeW $_{6}$ showed good activity against diabetes and Alzheimer's disease. ${ }^{33,34}$

In order to perform in vitro biological assays, we first prepared aqueous solutions of $\mathbf{T e W}_{\mathbf{6}}$, $\mathrm{TiW}_{11} \mathrm{Co}$, and $\mathbf{T i}_{2} \mathbf{P} \mathbf{W}_{10}$ and we determined their physico-chemical characteristics $(\mathrm{pH}$, osmolarity, Zeta potential) (Table1) and their biocompatibility. The POMs were stable in aqueous solution up to 6 months stored at $4^{\circ} \mathrm{C}$. Indeed, a concentration decrease of 3.25, 5.05 and $4.45 \%$ was observed for $\mathbf{T e W}_{\mathbf{6}}, \mathbf{T i W}_{\mathbf{1 1}} \mathrm{Co}$ and $\mathbf{T i}_{\mathbf{2}} \mathbf{P W}_{\mathbf{1 0}}$ respectively, after 6 months. In the hemolysis assay, no significant hemolysis caused by the POM solutions was observed, indicating good biocompatibility. (Data available in Supplementary info). The tonicity and $\mathrm{pH}$ values were suitable for the following cell experiments.

Therefore, to evaluate the anti-Zika virus activity of the three POMs, we performed virus inhibition assays against two Zika virus strains, the 1947 Uganda MR766 and the 2013 French Polynesia HPF2013, representing the African and the Asian lineage respectively. The cells were treated with decreasing concentrations of POMs before, during and after infection, in order to use a complete protection assay. As shown in Table 2, all three POMs were active against both ZIKV strains with half maximal effective concentrations ( $\mathrm{EC}_{50 \mathrm{~S}}$ ) ranging from 0.63 to $2.52 \mu \mathrm{M}$. Moreover, in order to assess the specificity of the anti-ZIKV activity of the POMs, they were tested against the human rotavirus (HRoV), an unrelated RNA virus belonging to the Reoviridae family. Interestingly, we did not observe any inhibition. Next, to exclude the possibility that this antiviral activity was due to a cytotoxic 
effect of the POMs, viability assays were carried out on uninfected cells, challenged with the compounds under the same conditions as the virus inhibition assays. The $\mathrm{CC}_{50}$ s were different for all three POMs $\left(\mathbf{T e W}_{6} \mathrm{CC}_{50}=210.1 \mu \mathrm{M}, \mathrm{TiW}_{11} \mathrm{Co}_{\mathrm{C}} \mathrm{CC}_{50}=97.08 \mu \mathrm{M}, \mathrm{Ti}_{\mathbf{2}} \mathbf{P W}_{10} \mathrm{CC}_{50}\right.$ $>225 \mu \mathrm{M})$, and demonstrated that they are not toxic at the concentrations used in the antiviral assays. The Selectivity Index (SI) of $\mathbf{T i}_{2} \mathbf{P W}_{\mathbf{1 0}}$ was the most favorable one, so we decided to concentrate our research on the study of the mechanism of action of this polyanion. All the experiments were performed with the two Zika virus strains used for the initial screening. We first investigated whether the antiviral activity of $\mathbf{T i}_{\mathbf{2}} \mathbf{P} \mathbf{W}_{\mathbf{1 0}}$ was exerted via direct inactivation of the viral particles. The ZIKV particles were incubated with a concentration of $\mathbf{T i}_{2} \mathbf{P W}_{10}$ that reduces almost completely the virus infection (EC90) and then the viral titer was determined at high dilutions at which the polyanion was no longer active when added to cells. As depicted in Figure 1A, there was no significant difference between the titer of treated virus and the titer of untreated control, demonstrating that $\mathbf{T i}_{2} \mathbf{P W}_{10}$ is not able to impair extracellular viral particles. Having excluded the viral particle as the target of the antiviral activity of $\mathbf{T i}_{\mathbf{2}} \mathbf{P} \mathbf{W}_{\mathbf{1 0}}$, further experiments were performed to investigate whether this polyanion acted directly on cells or on essential steps of the ZIKV replicative cycle. Vero cells were pre-treated with decreasing dilutions of the polyanion for 2 hours before virus infection; as reported in Figure 1B, the infection of both ZIKV strains was not inhibited even at the highest tested concentration. Hence, we explored the possibility that $\mathbf{T i}_{\mathbf{2}} \mathbf{P} \mathbf{W}_{\mathbf{1 0}}$ treatment could affect the early steps of the ZIKV replicative cycle. Binding assays were performed allowing the virus to bind host cell surface in the presence of a high concentration of $\mathbf{T i}_{\mathbf{2}} \mathbf{P} \mathbf{W}_{\mathbf{1 0}}$. The results (Figure $2 \mathrm{~A}$ ) demonstrated that the treatment did not significantly reduce $(p>0.05)$ the titer of viral particles bound to the cell surface, thus suggesting that inhibition occurs at a post-binding stage. To verify this hypothesis, we treated cells immediately after virus attachment, i.e. during virus entry into the host cell. In this case (Figure $2 \mathrm{~B}$ ), we observed a marked antiviral activity of $\mathbf{T i}_{\mathbf{2}} \mathbf{P} \mathbf{W}_{\mathbf{1 0}}$ against both, MR766 and HPF2013, ZIKV strains ( $E_{50}=1.11$ and $1.25 \mu \mathrm{M}$ respectively). To exclude an additional antiviral action of $\mathbf{T i}_{\mathbf{2}} \mathbf{P} \mathbf{W}_{\mathbf{1 0}}$ on the last steps of the ZIKV replicative cycle, we executed focus reduction assays adding the polyanion to cells immediately after virus entry into the host cell (post-entry assay). We stopped the treatment at 24 hours post-infection, i.e. at the end of the first replicative cycle, in order to avoid inhibition of the entry step of the upcoming viral progeny. As shown in Figure $2 \mathrm{C}$, the post-entry treatment 
did not reduce virus infectivity, suggesting that only the entry step is targeted by $\mathbf{T i}_{\mathbf{2}} \mathbf{P} \mathbf{W}_{\mathbf{1 0}}$. To confirm the inhibition of the ZIKV entry step, immunofluorescence experiments were performed by adding the polyanion ( $\mathrm{EC}_{99}$ ) during the virus entry step or immediately after the entry phase (post-entry). As reported in Figure 2D (MR766 experiments) and Figure 2E (experiments with HPF2013), it was possible to detect a strong red signal of ZIKV protein E only in the untreated and in the post-entry treated samples. The number of red infected cells in the post-entry treated samples was comparable to the one of the untreated control. On the contrary, the number of infected cells in the entry-treated samples was considerably reduced. All together these data indicate that the entry step is the target of the $\mathrm{Ti}_{2} \mathbf{P W}_{10}$ antiviral activity. Finally, to complete the in vitro analysis of the antiviral potential of $\mathbf{T i}_{2} \mathbf{P W}_{10}$ against ZIKV strains, virus yield reduction assays were performed by treating cells during and after infection and allowing multiple cycles of viral replication to occur before measuring the production of infectious viruses. The results (Figure 3) demonstrated that $\mathbf{T i}_{2} \mathbf{P W}_{\mathbf{1 0}}$ significantly reduces the viral progeny production of both ZIKV strains $(p<0.001)$.

Previously, researchers focused on the antiviral properties of POMs because they are generally nontoxic to normal cells. Indeed, several studies reported the broad spectrum antiviral activities of POMs against different types of respiratory-viruses, as RSV, FluV A, FluV B, PfluV and SARS, ${ }^{35,36}$ against HCV and DENV, ${ }^{36-38}$ belonging to the same family of ZIKV, and against others, as HIV, HSV-1, HSV-2 and HBV. ${ }^{23,38,39}$ Herein, we showed that three heteropolytungstates, never tested before as antiviral agents, are endowed with a strong antiviral activity against ZIKV and we demonstrated their good biocompatibility. For the first time, POMs have been tested against two ZIKV strains and we can now include ZIKV in the list of pathogens targeted by the wide spectrum of action of POMs. Of note, we did not observe any inhibition against the human rotavirus, a taxonomically unrelated RNA virus. All together these results indicate that $\mathbf{T e W}_{6}, \mathbf{T i W}_{\mathbf{1 1}}$ Co and $\mathbf{T i}_{\mathbf{2}} \mathbf{P} \mathbf{W}_{\mathbf{1 0}}$ exert a specific and not strain-restricted anti-ZIKV effect. In future experiments, we will investigate the antiviral action of $\mathrm{TeW}_{6}, \mathrm{TiW}_{\mathbf{1 1}} \mathrm{Co}$ and $\mathrm{Ti}_{\mathbf{2}} \mathbf{P W}_{\mathbf{1 0}}$ against other RNA and DNA viruses. Some other POMs have already been investigated for their mechanism of action, which commonly depends on their shape, size and composition. Various studies reported on the inhibition of the early steps of an infection: for instance, Shigeta et al., ${ }^{38}$ demonstrated that the tri-vanadium-containing sandwich-type polyanion $\left[(\mathrm{VO})_{3}\left(\mathrm{SbW}_{9} \mathrm{O}_{33}\right)_{2}\right]^{11-}$ affects the 
157 binding of HIV to the cell membrane and the syncytium formation between HIV-infected 158 and uninfected cells; another biochemical study, ${ }^{39}$ reports that the ability of the tri159 niobium-containing Keggin ion $\left[\mathrm{SiW}_{9} \mathrm{Nb}_{3} \mathrm{O}_{40}\right]^{7-}$ to prevent the binding and fusion process of 160 different viruses is mainly due to its localization on the cell surface; finally, Barnard et al., ${ }^{35}$ 161 indicate the alteration of the attachment step as the primary mode of RSV inhibition by 162 POMs of several structural classes. Consistent with these findings, we demonstrated that $163 \mathrm{Ti}_{2} \mathbf{P W}_{10}$ acts as inhibitor of the entry process of ZIKV into the host cell. By contrast, no 164 inhibition was observed at the binding stage. Further experiments are necessary to identify 165 the cellular localization of this polyanion and to clarify its molecular mechanism of action.

166 In conclusion, we have discovered that the Keggin-type POM Ti $\mathbf{P W}_{10}$ inhibits ZIKV infection 167 by hampering the entry process of the virus into the host cell. Since specific antivirals 168 against ZIKV are not available, this polyanion could be a good starting point for the 169 development of novel and efficient antiviral pharmaceuticals.

170 


\section{Abbreviations}

178 ZIKV, zika virus; HRoV, human rotavirus; RSV, respiratory syncytial virus, FluV A; influenza virus 179 type A, FluV B; influenza virus type B; PfluV, parainfluenza virus; SARS, severe acute respiratory 180 syndrome; HCV, hepatitis C virus; DENV, dengue virus; HIV, human immunodeficiency virus; HSV-1, 181 herpes simplex virus type 1; HSV-2, herpes simplex virus type 2; HBV, hepatitis B virus; POMs, 182 polyoxometalates; $\mathrm{EC}_{50}$, half maximal effective concentration; $\mathrm{EC}_{90}, 90 \%$ effective concentration; $183 \mathrm{CC}_{50}$, half maximal cytotoxic concentration; $\mathrm{SI}$, selectivity index; n.a., not assessable; $\mathrm{Cl}$, confidence 184 interval; PFU, plaque forming unit; PFU/ml, plaque forming unit per $\mathrm{ml}$;

\section{Declaration of interest}

186 None.

\section{Acknowledgements}

188 This work was financially supported by the University of Turin. [Grant number RILO 2018]

189 Appendix A. Supplementary data: Supplementary data related to this article can be found at 
190

References

192

193

194

195

196

197

198

199

200

201

202

203

204

205

206

207

208

209

210

211

212

213

214

215

216

217

218

219

220

1 J-C. Saiz, Á. Vázquez-Calvo, A.B. Blázquez, T. Merino-Ramos, E. Escribano-Romero, M.

A. Martín-Acebes, Front Microbiol, Zika Virus: the Latest Newcomer, 2016, 7, 496. doi: 10.3389/fmicb.2016.00496

2 D. Musso, C. Roche, E. Robin, T. Nhan, A. Teissier, V-M. Cao-Lormeau, Emerg Infect Dis, Potential Sexual Transmission of Zika Virus, 2015, 21, 359-61. doi: 10.3201/eid2102.141363

3 J. Mlakar, M. Korva, N. Tul, M. Popović, M. Poljšak-Prijatelj, J. Mraz, M. Kolencet, K. R. Rus, T. V. Vipotnik, V. F. Vodušek, A. Vizjak, J. Pižem, M. Petrovec, T. A. Županc, N Engl J Med, Zika Virus Associated with Microcephaly, 2016, 374, 951-8. doi: 10.1056/NEJMoa1600651

4 I. J. F. Motta, B. R. Spencer, S. G. Cordeiro da Silva, M. B. Arruda, J. A. Dobbin, Y. B. M. Gonzaga, I. P. Arcuri, R. C. B. S. Tavares, E. H. Atta, R. F. M. Fernandes, D. A. Costa, L. J. Ribeiro, F. Limonte, L. M. Higa, C. M. Voloch, R. M. Brindeiro, A. Tanuri, O. C. Ferreira, N Engl J Med, Evidence for Transmission of Zika Virus by Platelet Transfusion, 2016, 375, 1101-3. doi: 10.1056/NEJMc1607262

5 E. S. Paixão, F. Barreto, M. da Glória Teixeira, N. da Conceição, M. Costa, L. C. Rodrigues, Am J Public Health, Epidemiology, and Clinical Manifestations of Zika: A Systematic Review, 2016, 106, 606-12. doi: 10.2105/AJPH.2016.303112

6 S. A. Rasmussen, D. J. Jamieson, M. A. Honein, L. R. Petersen.. N Engl J Med, Zika Virus and Birth Defects - Reviewing the Evidence for Causality, 2016, 374, 1981-7. doi: 10.1056/NEJMsr1604338

7 V. M. Cao-Lormeau, A. Blake, S. Mons, S. Lastere, C. Roche, J. Vanhomwegen, T. Dub, L. Baudouin, A. Teissier, P. Larre, A.L. Vial, C. Decam, V. Choumet, S.K. Halstead, H. J. Willison, L. Musset, J. C. Manuguerra, P. Despres, E. Fournier, H. P. Mallet, D. Musso, A. Fontanet, J. Neil, F. Ghawché, Lancet Lond Engl, Guillain-Barré Syndrome outbreak caused by ZIKA virus infection in French Polynesia, 2016, 387, 1531-9. doi: 10.1016/S0140-6736(16)00562-6

8 P. Brasil , J. P. Pereira, M. E. Moreira, R. M. R. Nogueira, L. Damasceno, M. Wakimoto, R. S. Rabello, S. G. Valderramos, U.-A. Halai, T. S. Salles, A. A. Zin, D. Horovitz, P. Daltro, M. Boechat, C. Raja Gabaglia, P. Carvalho de Sequeira, J. H. Pilotto, R. Medialdea-Carrera, D. Cotrim da Cunha, L. M. Abreu de Carvalho, M. Pone, A. Machado Siqueira, G. A. Calvet, A. E. Rodrigues Baião, E. S. Neves, P. R. Nassar de Carvalho, R. H. Hasue, P. B. Marschik, C. Einspieler, C. Janzen, J. D. Cherry, A. M. Bispo de Filippis, K. Nielsen-Saines, N Engl J Med, Zika 
221 Virus Infection in Pregnant Women in Rio de Janeiro, 2016, 375, 2321-34. doi: 222 10.1056/NEJMoa1602412

2239 M. McCarthy, BMJ, Microcephaly risk with Zika infection is $1-13 \%$ in first trimester, 224 study shows, 2016, 353, i3048. doi: https://doi.org/10.1136/bmj.i3048

22510 M. R. Duffy, T. -H. Chen, W. T. Hancock, A. M. Powers, J. L. Kool, R. S. Lanciotti, M. 226 Pretrick, M. Marfel, S. Holzbauer, C. Dubray, L. Guillaumot, A. Griggs, M. Bel, A. J. Lambert, J. 227 Laven, O. Kosoy, A. Panella, B. J. Biggerstaff, M. Fischer, E. B. Hayes, N Engl J Med, Zika virus 228 outbreak on Yap Island, Federated States of Micronesia, 2009, 360, 2536-43. doi: 229 10.1056/NEJMoa0805715

23011 V. M. Cao-Lormeau, C. Roche, A. Teissier, E. Robin, A. L. Berry, H. P. Mallet, A. A. Sall, D. 231 Musso, Emerg Infect Dis, Zika virus, French polynesia, South pacific, 2013, 2014, 20, 1085-6. 232 doi: 10.3201/eid2006.140138.

23312 Y. Simonin, D. van Riel, P. Van de Perre, B. Rockx, S. Salinas, PLoS Negl Trop Dis, 234 Differential virulence between Asian and African lineages of Zika virus 2017, 11. doi: 235 10.1371/journal.pntd.0005821

23613 Q. Shao, S. Herrlinger, Y.N. Zhu, M. Yang, F. Goodfellow, S. L. Stice, X.P. Qi, M. A. Brindley, 237 J.F. Chen, The Company of Biologists, 2017, 144, 4114-4124, The African Zika virus MR-766 238 is more virulent and causes more severe brain damage than current Asian lineage and 239 dengue virus. doi:10.1242/dev.156752

24014 J. T. Beaver, N. Lelutiu, R. Habib, I. Skountzou, Front. Immunol., Evolution of Two Major 241 Zika Virus Lineages: Implications for Pathology, Immune Response, and Vaccine 242 Development, 2018, 9, 1640. doi: 10.3389/fimmu.2018.01640

24315 CDC, https://www.cdc.gov/zika/reporting/case-counts.html, (accessed May 2018).

24416 PAHO WHO, 245 https://www.paho.org/hq/index.php?option=com_content\&view=article\&id=12390\%3Azika246 cumulative-cases\&catid=8424\%3Acontents\&ltemid=42090\&lang=en, (accessed May 2018)

24717 J. M. Richner, M. S. Diamond, Curr Opin Immunol, Zika virus vaccines: immune 248 response, current status, and future challenges, 2018, 53, 130-6. doi: 249 10.1016/j.coi.2018.04.024

25018 J. C. Saiz, M. A. Martín-Acebes, Antimicrob Agents Chemother, The Race To Find 251 Antivirals for Zika Virus, 2017, 61. doi: 10.1128/AAC.00411-17

25219 M. T. Pope, Heteropoly and Isopoly Oxometalates, Springer, Berlin, 1983. 
25320 M. T. Pope, A. Müller, Angew. Chem. Int. Ed. Engl, Polyoxometalate Chemistry: An Old 254 Field with New Dimensions in Several Disciplines, 1991, 30, 34-48. 255 https://doi.org/10.1002/anie.199100341

25621 M. T. Pope, U. Kortz, Polyoxometalates, in Encyclopedia of Inorganic and Bioinorganic 257 Chemistry, John Wiley, 2012. https://doi.org/10.1002/9781119951438.eibc0185.pub2

25822 S. G. Sarafianos, U. Kortz, M. T. Pope, M. J. Modak, Biochem. J., Mechanism of 259 polyoxometalate-mediated inactivation of DNA polymerases: an analysis with HIV-1 reverse 260 transcriptase indicates specificity for the DNA-binding cleft, 1996, 319, 619-626. doi: $261 \quad 10.1042 / \mathrm{bj} 3190619$

26223 J. T. Rhule, C. L. Hill, D. A. Judd, R. F. Schinazi, Chem. Rev., Polyoxometalates in 263 Medicine, 1998, 98, 327-358. doi: 10.1021/cr960396q

26424 B. Hasenknopf, Frontiers Biosci., Polyoxometalates: introduction to a class of inorganic 265 compounds and their biomedical applications, 2005, 10, 275-287. doi: 10.2741/1527

26625 S. G. Mauracher, C. Molitor, R. Al-Oweini, U. Kortz, A. Rompel, Acta Crystallogr., Sect. 267 D, Latent and active abPPO4 mushroom tyrosinase cocrystallized with 268 hexatungstotellurate(VI) in a single crystal, 2014, 70, 2301-2315. doi: $26910.1107 /$ S1399004714013777

27026 H. Giang, T. Ly, G. Absillis, R. Janssens, P. Proost, T. N. Parac-Vogt, Angew. Chem. Int. 271 Ed., Highly Amino Acid Selective Hydrolysis of Myoglobin at Aspartate Residues as Promoted 272 by Zirconium(IV)-Substituted Polyoxometalates, 2015, 54, 7391-7394. doi: 273 10.1002/anie.201502006

27427 P. Yang, Z. Lin, B. S. Bassil, G. Alfaro-Espinoza, M. S. Ullrich, M.-X. Li, C. Silvestru, U. 275 Kortz, Inorg. Chem, Tetra-Antimony(III)-Bridged 18-Tungsto-2-Arsenates(V), [(LSb(III))4(A- $\alpha$ $276 \mathrm{As}(\mathrm{V}) \mathrm{W}$ 9034)2](10-) ( $\mathrm{L}=\mathrm{Ph}, \mathrm{OH})$ : Turning Bioactivity On and Off by Ligand Substitution, 2016, 277 55, 3718-3720. doi: 10.1021/acs.inorgchem.6b00107

27828 M. Selman, C. Rousso, A. Bergeron, H.H. Son, R. Krishnan, N.A. El-Sayes, O. Varette, A. 279 Chen, F. Le Boeuf, F. Tzelepis, J.C. Bell, D.C. Crans, J.S. Diallo, Mol Ther, Multi-modal 280 Potentiation of Oncolytic Virotherapy by Vanadium compounds, 2018, 26(1), 56-69. doi: $281 \quad$ 10.1016/j.ymthe.2017.10.014

28229 K. Schmidt, G. Schrobilgen, J. Sawyer, Acta Crystallogr. Sect. C: Cryst. Struct. Commun., 283 Hexasodium hexatungstotellurate(VI) 22-hydrate, 1986, 42, 1115-1118. doi: $284 \quad 10.1107 /$ S0108270186093204 
31 P. J. Domaille, W. H. Knoth, Inorg. Chem., Ti2W10P0407- and

[CpFe(CO)2Sn]2W10PO385-. Preparation, properties, and structure determination by tungsten-183 NMR, 1983, 22, 818-822. doi: 10.1021/ic00147a023

32 M. B. Čolović, B. Medić, M. Ćetković, T. K. Stevović, M. Stojanović, W. W. Ayass, A. S.

Mougharbel, M. Radenković, M. Prostran, U. Kortz, Toxicol. Appl. Pharmacol., Toxicity evaluation of two polyoxotungstates with anti-acetylcholinesterase activity, 2017, 333, 68-75. doi: 10.1016/j.taap.2017.08.010

33 Z. Ilyas, H. S. Shah, R. Al-Oweini, U. Kortz, J. Iqbal, Metallomics, Antidiabetic potential of polyoxotungstates: in vitro and in vivo studies, 2014, 6, 1521-1526. doi: 10.1039/c4mt00106k

34 J. Iqbal, M. Barsukova-Stuckart, M. Ibrahim, S. U. Ali, A. A. Khan, U. Kortz, Med. Chem. Res., Polyoxometalates as potent inhibitors for acetyl and butyrylcholinesterases and as potential drugs for the treatment of Alzheimer's disease, 2013, 22, 1224-1228. doi: $10.1007 / \mathrm{s} 00044-012-0125-8$

35 D.L. Barnard, C.L. Hill, T. Gage, J.E. Matheson, J.H. Huffman, R.W. Sidwell, M. I Otto, R.

F. Schinazi, Antiviral Res, Potent inhibition of respiratory syncytial virus by polyoxometalates of several structural classes, 1997, 34, 27-37. https://doi.org/10.1016/S0166-3542(96)01019303

S. Shigeta, S. Mori, T. Yamase, N. Yamamoto, N. Yamamoto, Biomed Pharmacother

Biomedecine Pharmacother, Anti-RNA virus activity of polyoxometalates, 2006, 60, 211-9. doi:10.1016/j.biopha.2006.03.009

Y. Qi, Y. Xiang, J. Wang, Y. Qi, J. Li, J. Niu, J. Zhong, Antiviral Res, Inhibition of hepatitis C virus infection by polyoxometalates, $2013,100,392-8$. doi: 10.1016/j.antiviral.2013.08.025 38 S. Shigeta, S. Mori, E. Kodama, J. Kodama, K. Takahashi, T. Yamase, Antiviral Res, Broad spectrum anti-RNA virus activities of titanium and vanadium substituted polyoxotungstates, 2003, 58, 265-71. https://doi.org/10.1016/S0166-3542(03)00009-3 Mater Interfaces, Broad-spectrum antiviral property of polyoxometalate localized on a cell 


\begin{tabular}{cccc}
\hline POM sample & $\mathbf{p H}$ & $\begin{array}{c}\text { Osmolarity } \\
\text { (mOsm) }\end{array}$ & $\begin{array}{c}\text { Zeta potential } \\
\text { (mV) }\end{array}$ \\
\hline $\mathrm{TeW}_{6}$ & 5.65 & 324 & $-6.06 \pm 3.11$ \\
$\mathrm{TiW}_{11} \mathrm{Co}_{\mathrm{m}}$ & 5.45 & 320 & $-6.95 \pm 3.49$ \\
$\mathrm{Ti}_{\mathbf{2}} \mathrm{PW}_{10}$ & 6.25 & 316 & $-5.31 \pm 1.95$ \\
\hline
\end{tabular}

Table1. Characteristics of POM aqueous solutions

318

\begin{tabular}{|c|c|c|c|c|c|}
\hline Compound & Virus & $\mathrm{EC}_{50}(\mu \mathrm{M})(95 \% \mathrm{Cl})$ & $\mathrm{EC}_{90}(\mu \mathrm{M})(95 \% \mathrm{Cl})$ & $\mathrm{CC}_{50}(\mu \mathrm{M})(95 \% \mathrm{Cl})$ & SI \\
\hline \multirow[t]{3}{*}{$\mathrm{TeW}_{6}$} & MR766 & $2.52(1.87-3.39)$ & $9.47(4.41-20.35)$ & $210.1(161.3-273.6)$ & 83.37 \\
\hline & HPF2013 & $0.71(0.53-0.96)$ & $6.12(3.29-11.39)$ & $210.1(161.3-273.6)$ & 295.91 \\
\hline & HRoV & n.a. & n.a. & $>75$ & - \\
\hline \multirow[t]{3}{*}{$\mathrm{TiW}_{11} \mathrm{Co}$} & MR766 & $1.04(0.80-1.35)$ & $5.19(2.87-9.38)$ & 97.08 (51.36 - 183.5) & 93.34 \\
\hline & HPF2013 & $0.70(0.57-0.87)$ & $1.41(1.02-1.94)$ & $97.08(51.36-183.5)$ & 138.68 \\
\hline & HRoV & n.a. & n.a. & $>75$ & - \\
\hline \multirow[t]{3}{*}{$\mathrm{Ti}_{2} \mathrm{PW}_{10}$} & MR766 & $0.63(0.51-0.78)$ & $3.51(2.19-5.63)$ & $>225$ & $>357.14$ \\
\hline & HPF2013 & $0.70(0.59-0.84)$ & $2.78(1.82-4.25)$ & $>225$ & $>321.42$ \\
\hline & HRoV & n.a. & n.a. & $>75$ & - \\
\hline
\end{tabular}

319 Table 2. Antiviral activity of $\mathrm{TeW}_{6}, \mathrm{TiW}_{11} \mathrm{Co}$ and $\mathrm{Ti}_{2} \mathrm{PW}_{10}$

$320 \mathrm{EC}_{50}$ : half maximal effective concentration; $\mathrm{EC}_{90}$ : $90 \%$ effective concentration; $\mathrm{CC}_{50}$ : half maximal cytotoxic concentration; SI: selectivity index; n.a.: not assessable; $\mathrm{Cl}$ : confidence interval 
A

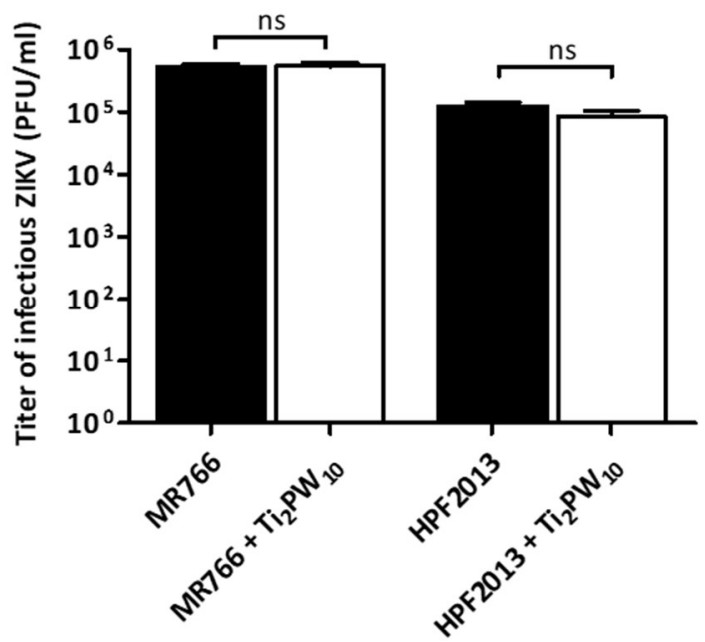

B

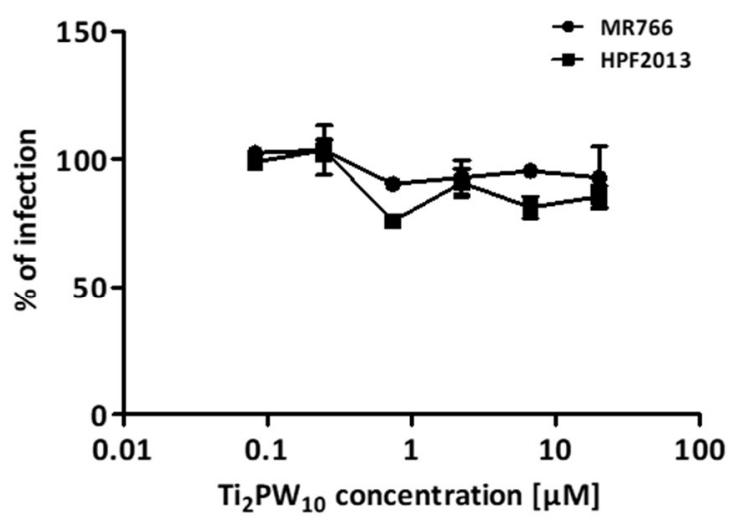

Figure 1: $\mathrm{Ti}_{2} \mathrm{PW}_{10}$ does not impair extracellular viral particles and the cells pre-treatment does not affect ZIKV infection. Panel $A$ shows the evaluation of the virucidal effect of $\mathrm{Ti}_{2} \mathbf{P W}_{10}$ on infectious ZIKV particles. Approximately $10^{5} \mathrm{PFU}$ of ZIKV (MR766 or HPF2013) plus EC90 of $\mathrm{Ti}_{\mathbf{2}} \mathbf{P W}_{10}$ were added to MEM and mixed in a total volume of $100 \mu \mathrm{L}$. The mixture was incubated for $2 \mathrm{~h}$ at $37^{\circ} \mathrm{C}$ then diluted serially to the non-inhibitory concentration of the test polyanion; the residual viral infectivity was determined by viral plaque assay. Panel B displays the effect of cells pretreatment with $\mathbf{T i}_{2} \mathbf{P} \mathbf{W}_{\mathbf{1 0}}$. Vero cells were pre-treated with serial dilutions of $\mathbf{T i}_{\mathbf{2}} \mathbf{P} \mathbf{W}_{\mathbf{1 0}}$ for 2 hours before infection. After washing, cells were infected with ZIKV and the number of viral plaques was evaluated after 72 hours. In panels A, the viral titers are expressed as PFU/ml and are shown as mean plus SEM for three independent experiments. In panels $B$, the number of viral plaques in the treated samples is expressed as a percentage of the untreated control and each point represents mean and SEM for three independent experiments. Experimental details are described in the Supplementary data file. 
A
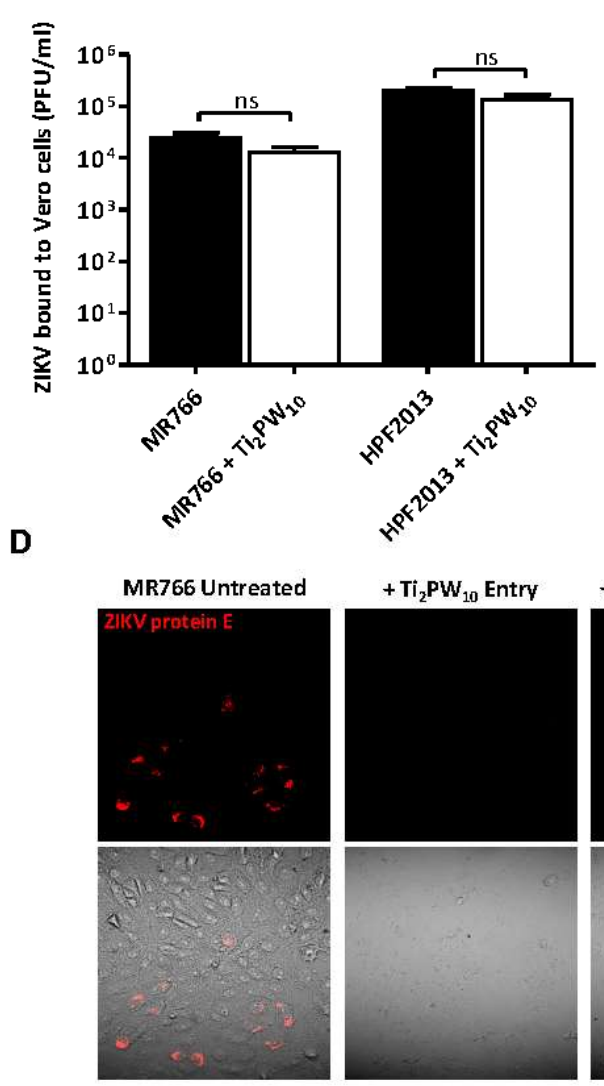

B

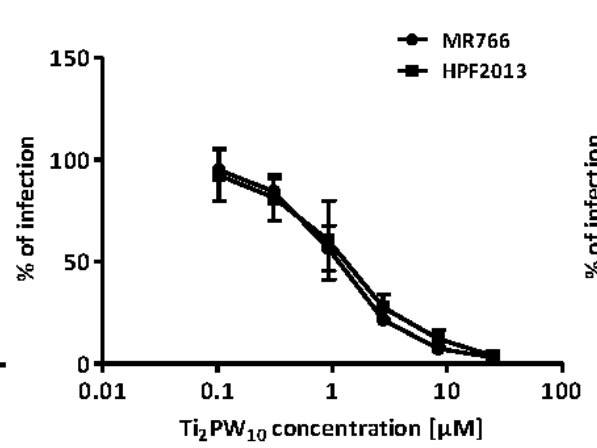

$\mathbf{E}$

C
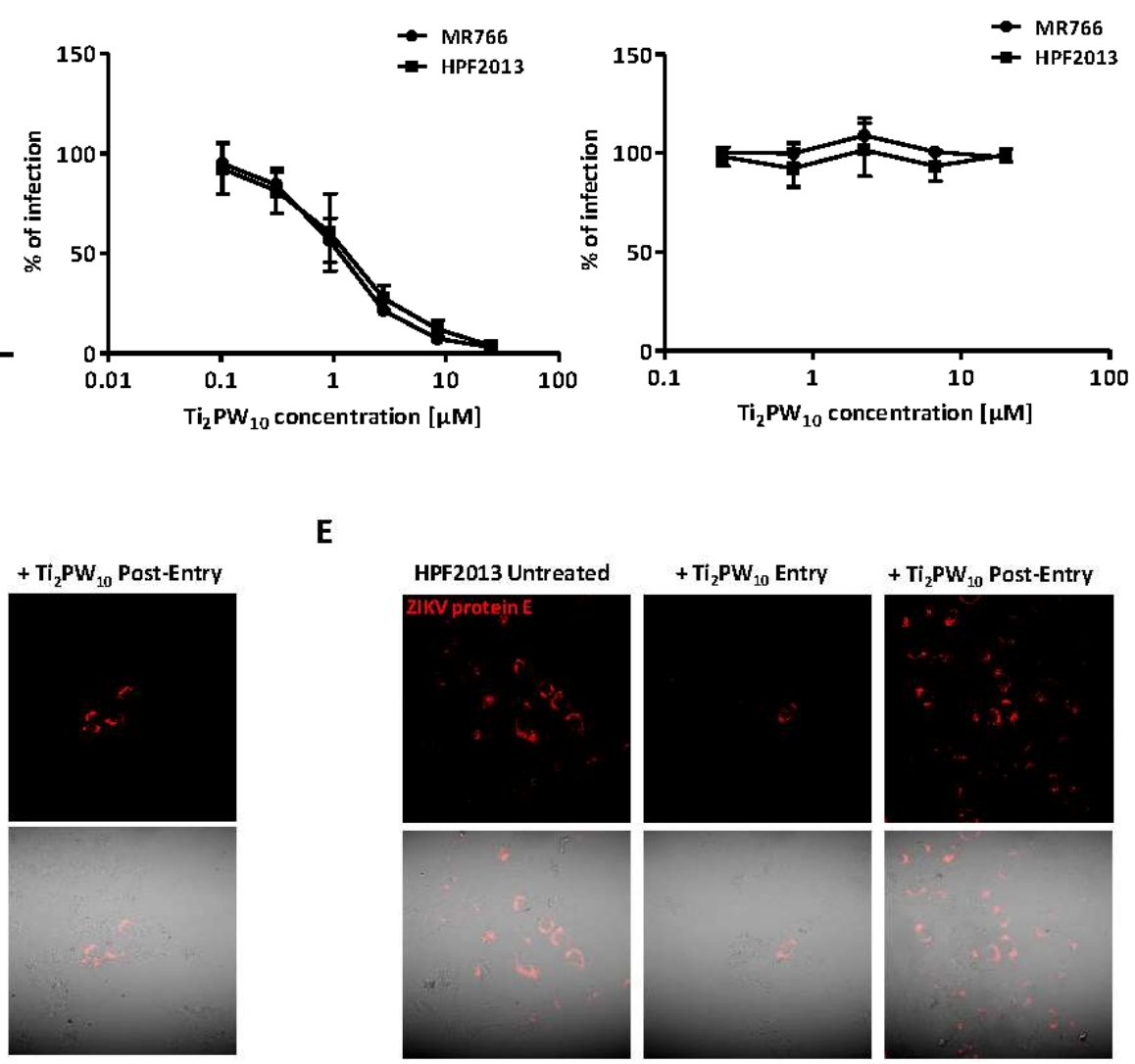

Figure 2: $\mathrm{Ti}_{2} \mathrm{PW}_{10}$ hampers the entry process of ZIKV into the host cell. In the binding assay (2A), ZIKV particles (MR766 or HPF2013, MOI=3) were allowed to attach to cells in presence of $\mathbf{T i}_{\mathbf{2}} \mathbf{P W}_{\mathbf{1 0}}$ (EC 90 ) for $2 \mathrm{~h}$ on ice. Cells were then washed to remove the unbound virus and subsequently subjected to three rounds of freeze-thawing to release bound virus. The lysate was clarified and the cell-bound virus titer was determined by viral plaque assay. Here, the viral titers are expressed as PFU/ml and are shown as mean plus SEM for three independent experiments. For the entry assay (2B), ZIKV (MR766 or HPF2013) was adsorbed for $2 \mathrm{~h}$ at $4^{\circ} \mathrm{C}$ on pre-chilled Vero cells. After the removal of the unbound virus, the temperature was shifted to $37^{\circ} \mathrm{C}$ to allow the entry of prebound virus in presence of serial dilutions of $\mathbf{T i}_{\mathbf{2}} \mathbf{P} \mathbf{W}_{\mathbf{1 0}}$. Subsequently, unpenetrated virus was inactivated with an incubation with citrate buffer followed by 3 washes. The number of viral plaques was evaluated after $72 \mathrm{~h}$. For the post-entry assay $(\mathbf{2 C})$, the same protocol of the entry assay was performed, but adding the polyanion after the incubation with citrate buffer for $24 \mathrm{~h}$.

The number of infected cells was assessed by indirect immunostaining after $24 \mathrm{~h}$, in order to avoid the inhibition of the entry step of the upcoming viral progeny. In panels $B, C$, the number of viral plaques or infected cells in the treated samples is expressed as a percentage of the untreated control and each point represents mean and SEM for three independent experiments. In figures 2D (MR766) and 2E (HPF2013), the entry and the post-entry assays were performed with a 
concentration of $\mathrm{Ti}_{2} \mathbf{P W}_{10}$ corresponding to $\mathrm{EC}_{99}$. After 30 hours of infection, cells were fixed and 357 subjected to immunofluorescence. The ZIKV protein E is visualized in red. All experimental details 358 are described in the Supplementary data file.

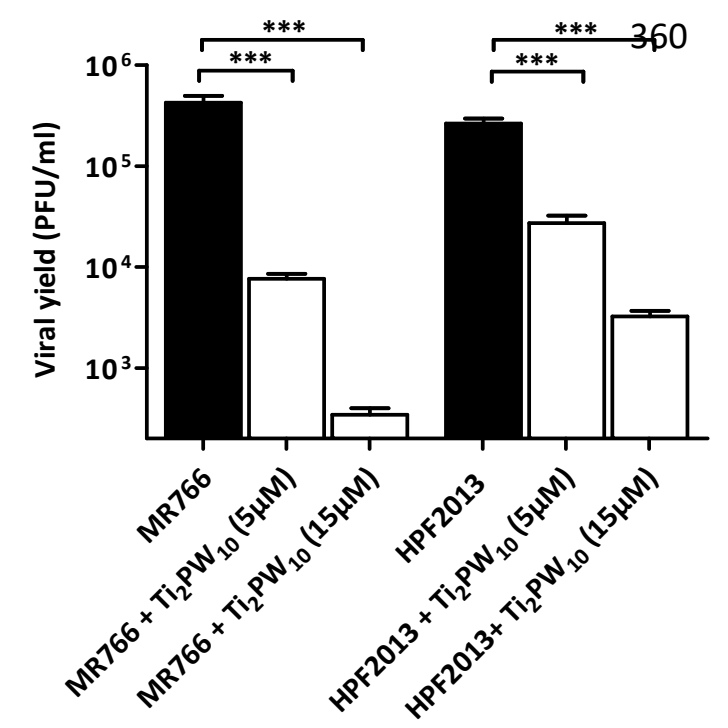

361 Figure 3: $\mathrm{Ti}_{2} \mathrm{PW}_{10}$ reduces $\mathrm{ZIKV}$ progeny production. To test the ability of $\mathrm{Ti}_{2} \mathrm{PW}_{10}$ compound to 362 inhibit multiple cycles of ZIKV replication, Vero cells were treated and infected with a mixture of $363 \mathrm{Ti}_{2} \mathrm{PW}_{10}(5 \mu \mathrm{M}$ or $15 \mu \mathrm{M})$ and ZIKV (MR766 or HPF2013, MOI=0.001) for 2 hours at $37^{\circ} \mathrm{C}$. The virus 364 inoculum was then removed and cells were incubated with medium containing the compound $365(5 \mu \mathrm{M}$ or $15 \mu \mathrm{M})$ until control cultures displayed extensive cytopathology. Supernatants were 366 clarified and cell-free virus infectivity titers were determined by the plaque assay. The viral titers 367 are expressed $\mathrm{PFU} / \mathrm{ml}$ and are shown as mean plus SEM for three independent experiments. $368\left(* * * \mathrm{P}_{\mathrm{Tstud}}<0.001\right)$ 
374 Rachele Francese, ${ }^{a}$ Andrea Civra, ${ }^{a}$ Massimo Rittà,, ${ }^{a}$ Manuela Donalisio, ${ }^{a}$ Monica Argenziano, ${ }^{b}$ 375 Roberta Cavalli, ${ }^{b}$ Ali S. Mougharbel, ${ }^{c}$ Ulrich Kortz, ${ }^{c^{*}}$ and David Lembo ${ }^{a^{*}}$

376

377 a Dept. of Clinical and Biological Sciences; Laboratory of Molecular Virology and Antiviral Research; 378 University of Turin; S. Luigi Gonzaga Hospital; Orbassano (Turin), Italy

$379 b^{b}$ Dept. of Drug Science and Technology; Innovative Pharmaceutical and Cosmetic Technology and 380 Nanotechnology Group; University of Turin, Italy

381 ' Department of Life Sciences and Chemistry, Jacobs University, Campus Ring 1, 28759 Bremen, 382 Germany 
A

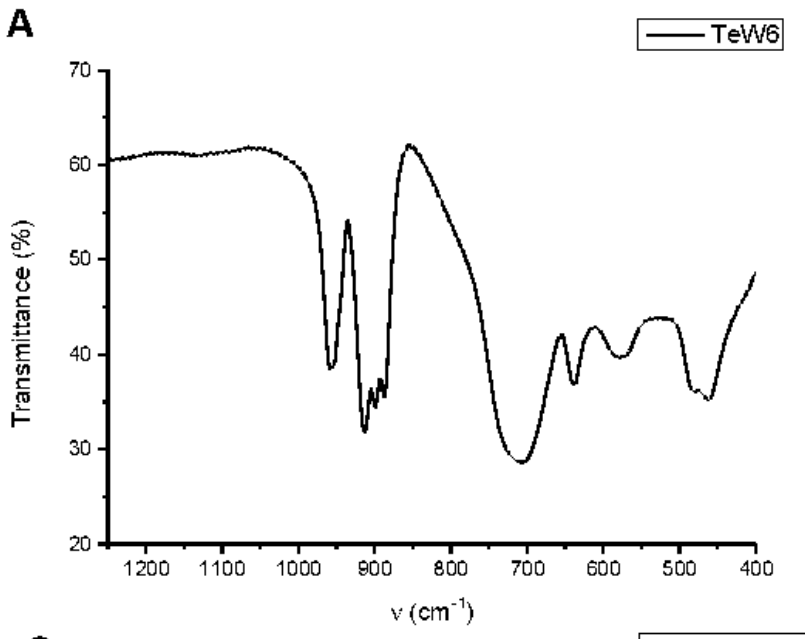

C

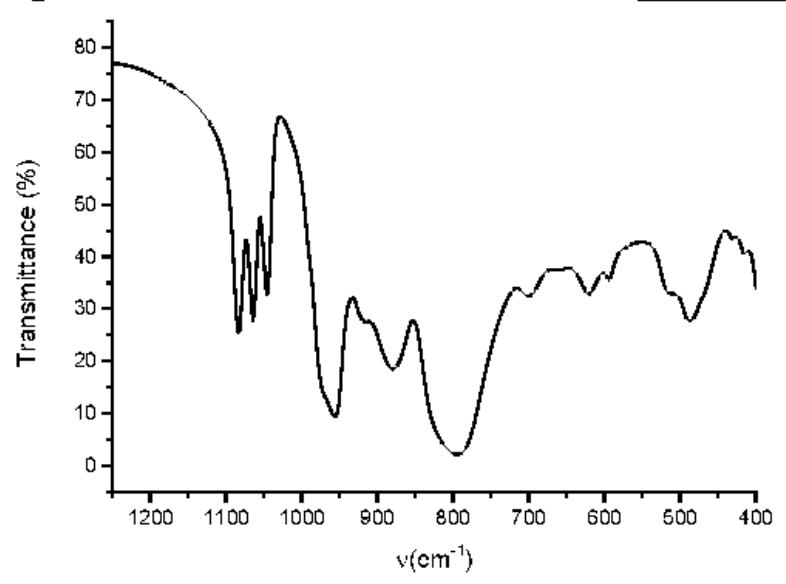

\section{B}

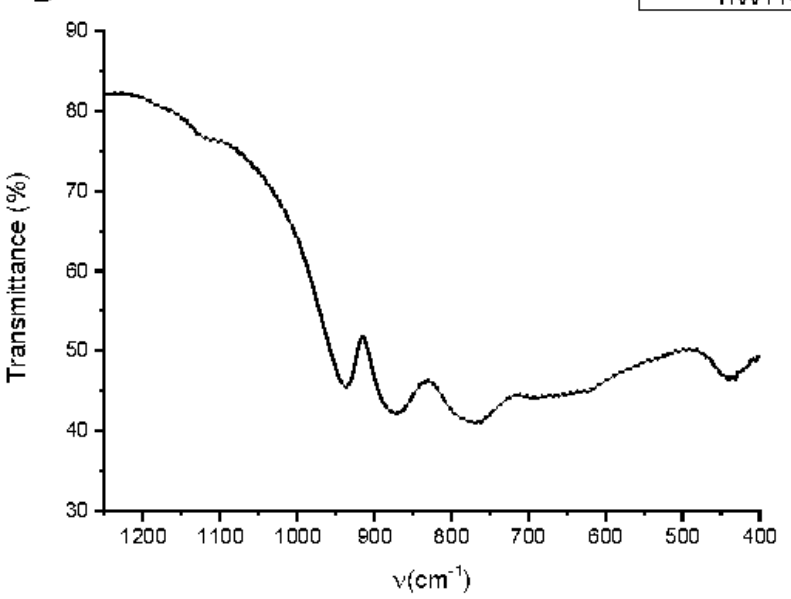

386

387

388 Supplementary figure 1: IR characterization of $\mathrm{TeW}_{6}, \mathrm{TiW}_{11} \mathrm{Co}_{0}$ and $\mathrm{Ti}_{2} \mathrm{PW}_{10}$

389 Panels $A, B, C$ show the infrared spectra (finger print region) of $\mathrm{TeW}_{6}, \mathrm{TiW}_{11} \mathrm{Co}$ and $\mathrm{Ti}_{2} \mathrm{PW}_{10}$. 
A TeW6 ${ }^{183}$ W NMR

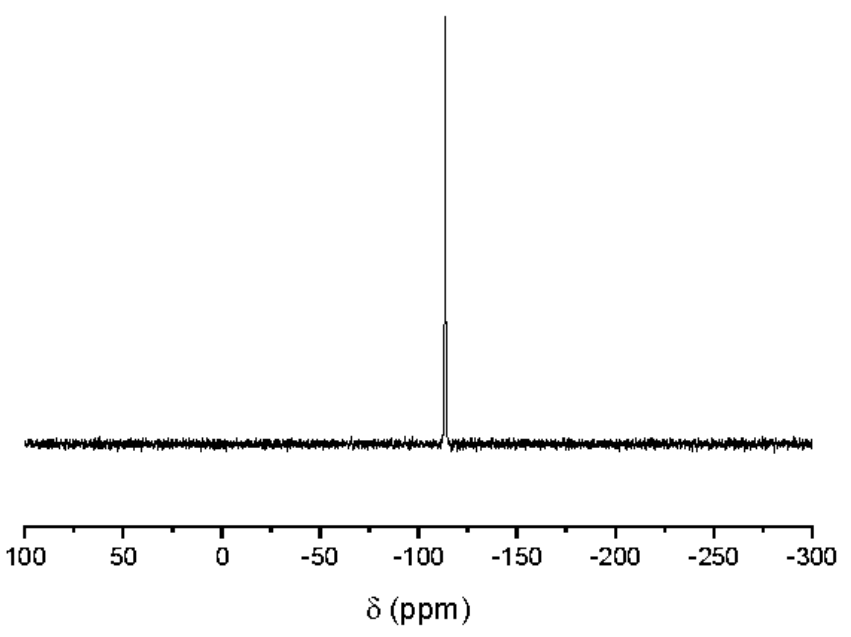

B

Ti2PW10 ${ }^{31}$ P NMR

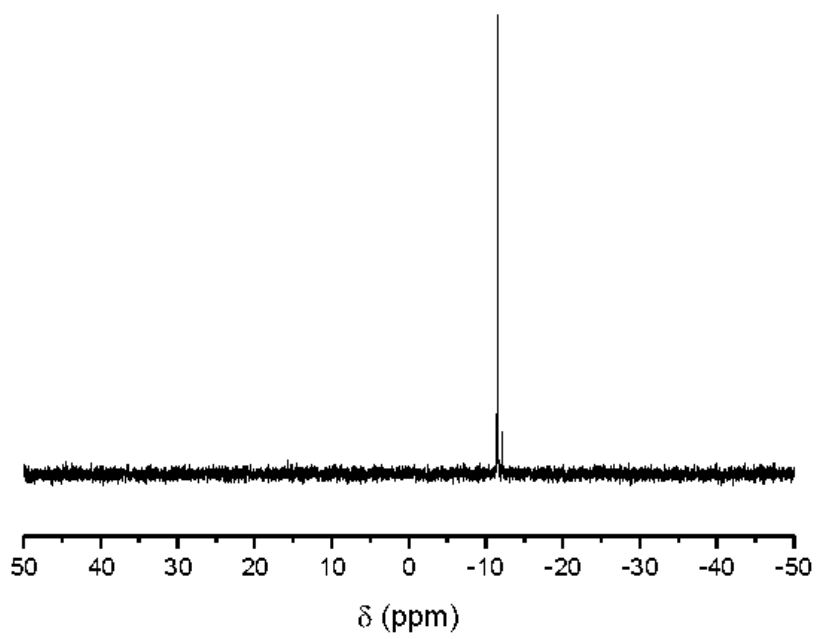

391

392 Supplementary figure 2: NMR spectra of $\mathrm{TeW}_{6}\left({ }^{183} \mathrm{~W}\right)(\mathrm{A})$ and $\mathrm{Ti}_{2} \mathrm{PW}_{10}\left({ }^{31} \mathrm{P}\right)(\mathrm{B})$ in $\mathrm{H}_{2} \mathrm{O} / \mathrm{D}_{2} \mathrm{O}$ at room 393 temperature

394 


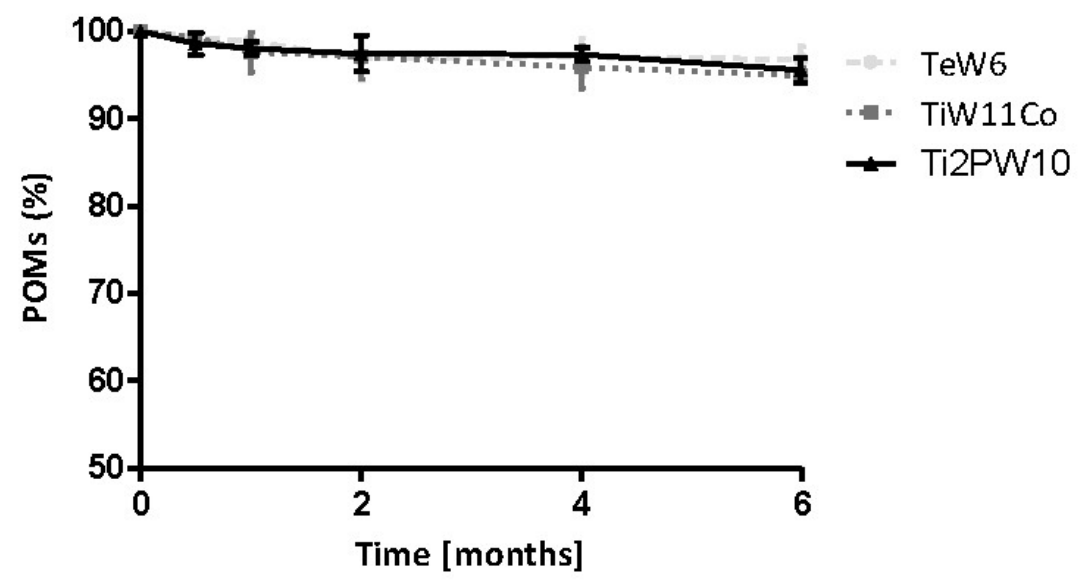

395

396 Supplementary figure 3: Stability over time for $\mathrm{TeW}_{6}, \mathrm{TiW}_{11} \mathrm{Co}$ and $\mathrm{Ti}_{2} \mathrm{PW}_{10}$ polyoxometalate 397 solutions

398

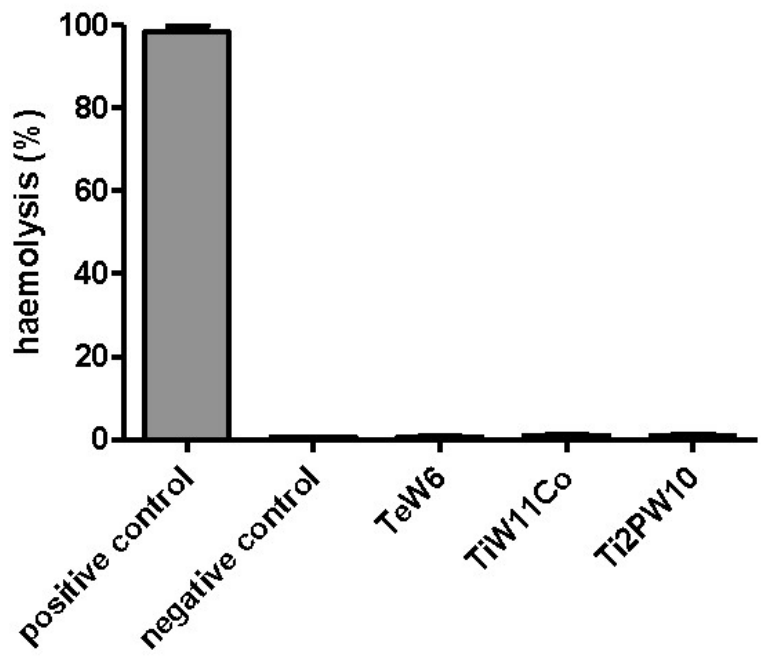

399

400 Supplementary figure 4: Hemolytic activity of aqueous POM solutions

401 


\section{Materials and methods}

\section{Cell lines and viruses}

African green monkey fibroblastoid kidney cells (Vero) (ATCC CCL-81) were cultured in Eagle's minimal essential medium (MEM; Sigma, St. Louis, MO) supplemented with heat-inactivated, $10 \%$ (v/v) fetal bovine serum (FBS) (Sigma). The embryonic human kidney cells (293T) (ATCC CRL-3216) and the african green monkey kidney epithelial cells (MA104) (ATCC CRL-2378.1) were grown as monolayer in Dulbecco's modified Eagle's medium (DMEM; Sigma) supplemented with heatinactivated 10\% FBS and 1\% Glutamax-I (Invitrogen, Carlsbad, CA). All media were supplemented with $1 \%(\mathrm{v} / \mathrm{v}$ ) antibiotic-antimycotic solution (Zell Shield, Minerva Biolabs, Berlin, Germany) and cells were grown at $37{ }^{\circ} \mathrm{C}$ in an atmosphere of $5 \%$ of $\mathrm{CO}_{2}$.

The antiviral assays against ZIKV were performed on Vero cells using MEM supplemented with $2 \%$ of FBS, unless otherwise stated.

\section{Viruses production}

Two strains of infectious Zika viruses (1947 Uganda MR766 and 2013 French Polynesia HPF13) were generated by transfection of 293T cells with two plasmids (pCDNA6.2 Zika MR766 Intron3115 HDVr MEG 0709165 and pCDNA6.2 Zika HPF2013 3864,9388Intron HDVr MEG091316 2) kindly provided by Prof. F. Di Cunto and Prof. M. J. Evans. ${ }^{1,2}$ Briefly, one day prior to transfection, $2.3 \times 10^{6} 293 \mathrm{~T}$ cells were seeded in $100 \mathrm{~mm}$ tissue culture dishes. $4.5 \mu \mathrm{g}$ of plasmid DNA were incubated with $27 \mu \mathrm{l}$ of Lipofectamine (Thermo Fisher Scientific, California, USA) and Opti-MEM (Sigma) in a final volume of $900 \mu l$ for 5 minutes at room temperature. The mixture was then used to transfect cells in a final volume of $5.5 \mathrm{ml}$ of DMEM 10\% FBS without antibiotics, for 5 hours at $37^{\circ} \mathrm{C}$ in $5 \%$ of $\mathrm{CO}_{2}$ atmosphere. Supernatants from transfected cells were collected 5 or 15 days post transfection (MR766 and HPF2013 strain respectively) and then titrated by plaque assay.

HRoV Wa (ATCC ${ }^{\circledR}$ VR-2018) were purchased from ATCC and activated with $5 \mu \mathrm{g} / \mathrm{ml}$ of porcine pancreatic trypsin type IX (Sigma, St. Louis, Mo.) for $30 \mathrm{~min}$ at $37^{\circ} \mathrm{C}$. It was propagated in MA104 cells by using DMEM containing $0.5 \mu \mathrm{g}$ of trypsin per $\mathrm{ml}$ as previously described. ${ }^{3}$

\section{Synthesis of POMs}

\subsection{Synthesis of $\mathrm{Na}_{6}\left[\mathrm{TeW}_{6} \mathrm{O}_{24}\right] \cdot 22 \mathrm{H}_{2} \mathrm{O}$ :}

A solution was prepared by dissolving $5.0 \mathrm{~g}(15.2 \mathrm{mmol})$ of $\mathrm{Na}_{2} \mathrm{WO}_{4} \cdot 2 \mathrm{H}_{2} \mathrm{O}$ and $0.6 \mathrm{~g}$ (2.6 mmol) of $\mathrm{Te}(\mathrm{OH})_{6}$ in $100 \mathrm{~mL}$ of water. The $\mathrm{pH}$ was adjusted to 5.0 using $\mathrm{HCl}(1 \mathrm{M})$ followed by heating at $100 \stackrel{\circ}{ } \mathrm{C}$ until the volume of the solution was about $75 \mathrm{ml}$. The solution was allowed to cool to room temperature and filtered. The filtrate was left at room temperature in an open beaker for one week and led to the formation of colorless crystals, which were collected by filtration and air-dried.

\subsection{Synthesis of $\mathrm{K}_{7}\left[\mathrm{Ti}_{2} \mathrm{~W}_{10} \mathrm{PO}_{40}\right] \cdot 6 \mathrm{H}_{2} \mathrm{O}$ :}


$6.0 \mathrm{~g}(43 \mathrm{mmol})$ of $\mathrm{NaH}_{2} \mathrm{PO}_{4}$ were added to a stirred solution of $\mathrm{Na}_{2} \mathrm{WO}_{4} \cdot 2 \mathrm{H}_{2} \mathrm{O}(30.0 \mathrm{~g}, 91$ $\mathrm{mmol})$ in water $(100 \mathrm{ml})$ followed by dropwise addition of $1.8 \mathrm{ml}(16 \mathrm{mmol})$ of $\mathrm{TiCl}_{4}$. The obtained white suspension was refluxed for 2 hours, cooled to room temperature and filtered. The filtrate was treated with $30 \mathrm{~g}$ of solid $\mathrm{KCl}$ and the white precipitate was collected by filtration. The precipitate was recrystallized in hot water to obtain the pure compound.

\subsection{Synthesis of $\mathrm{K}_{6} \mathrm{H}\left[\mathrm{TiCOW}_{11} \mathrm{O}_{40}\right]$ :}

$18.2 \mathrm{~g} \mathrm{(55} \mathrm{mmol)} \mathrm{of} \mathrm{Na}_{2} \mathrm{WO}_{4} \cdot 2 \mathrm{H}_{2} \mathrm{O}$ were dissolved in $100 \mathrm{ml}$ of water and the $\mathrm{pH}$ of the solution was adjusted to 6.3 using glacial acetic acid. To this solution, $10 \mathrm{ml}$ of $0.52 \mathrm{M}$ cobalt acetate solution were added. The obtained red solution was heated to $80{ }^{\circ} \mathrm{C}$ for approximately one hour until the color turned blue. To this solution, $10 \mathrm{ml}$ of $1 \mathrm{M} \mathrm{TiOSO}_{4}$ solution in $0.1 \mathrm{M} \mathrm{H}_{2} \mathrm{SO}_{4}$ were added dropwise under vigorous stirring. The pale blue mixture was refluxed for one hour, cooled to room temperature and treated with $10 \mathrm{~g} \mathrm{KCl}$. The precipitate was then filtered and the filtrate was cooled to $0 \stackrel{\circ}{ }$. Finally, $200 \mathrm{ml}$ of ethanol were added to the filtrate and the light blue precipitate was collected by suction filtration.

\section{Preparation of $\mathrm{TeW}_{6}, \mathrm{TiW}_{11} \mathrm{Co}$ and $\mathrm{Ti}_{2} \mathrm{PW}_{10}$ solutions}

The three POM salts $\mathrm{Na}_{6}\left[\mathrm{TeW}_{6} \mathrm{O}_{24}\right] \cdot 22 \mathrm{H}_{2} \mathrm{O}\left(\mathrm{Na}-\mathrm{TeW}_{6}\right), \mathrm{K}_{6} \mathrm{H}_{2}\left[\mathrm{TiW}_{11} \mathrm{CoO}_{40}\right] \cdot 13 \mathrm{H}_{2} \mathrm{O}\left(\mathrm{K}-\mathrm{TiW}_{11} \mathrm{Co}\right)$, and $\mathrm{K}_{7}\left[\mathrm{Ti}_{2} \mathrm{PW}_{10} \mathrm{O}_{40}\right] \cdot 6 \mathrm{H}_{2} \mathrm{O}\left(\mathrm{K}-\mathrm{Ti}_{2} \mathrm{PW}_{10}\right)$ were dissolved under mild stirring at room temperature in saline solution $(\mathrm{NaCl} 0.9 \% \mathrm{w} / \mathrm{v})$ at the concentration of $2 \mathrm{mg} / \mathrm{ml}$.

\section{Characterization of $\mathrm{TeW}_{6}, \mathrm{TiW}_{11} \mathrm{Co}$ and $\mathrm{Ti}_{2} \mathrm{PW}_{10}$ solutions}

The $\mathrm{pH}$ of the $\mathrm{POM}$ aqueous solutions was recorded at room temperature using a $\mathrm{pH}$ meter Orion model 420A.

The osmolarity of the POM aqueous solutions was measured using a Semi-Micro Osmometer K7400 Knauer, at room temperature.

The zeta potential was determined by electrophoretic mobility using a 90 Plus instrument (Brookhaven, NY, USA). The analysis was performed at room temperature, using POM aqueous solutions diluted with $\mathrm{NaCl} 0.9 \% \mathrm{w} / \mathrm{v}(1: 10 \mathrm{v} / \mathrm{v})$. For the zeta potential evaluation, samples of diluted formulations were placed in the electrophoretic cell, where an electric field of approximately $15 \mathrm{~V} / \mathrm{cm}$ was applied.

\section{Quantitative determination of POMs}

The quantitative determination of the POMs in the aqueous solutions was performed using UV-VIS spectrophotometer (Beckman Coulter DU730). A preliminary evaluation of the UV spectra of the 
compounds was carried out by spectrophotometric analysis collecting the absorbance data in the range between 200 and $800 \mathrm{~nm}$ to identify the absorbance maximum ( $\lambda$ max) peak.

Linear calibration curves were obtained over the concentration range of $0-100 \mu \mathrm{g} / \mathrm{mL}$, with a regression coefficient of 0.999 for all the compounds.

\section{Stability overtime of $\mathrm{TeW}_{6}, \mathrm{TiW}_{11} \mathrm{Co}$ and $\mathrm{Ti}_{2} \mathrm{PW}_{10}$ solutions}

The stability of polyoxometalate aqueous solutions was evaluated over time, determining the POM concentrations in the solutions by UV-VIS spectroscopy analysis.

\section{Evaluation of $\mathrm{TeW}_{6}, \mathrm{TiW}_{11} \mathrm{Co}$ and $\mathrm{Ti}_{2} \mathrm{PW}_{10}$ solution biocompatibility}

To assess the biocompatibility of POM aqueous solutions the hemolysis assay was performed.

For hemolytic activity determination, 100 microliters of samples were incubated at $37^{\circ} \mathrm{C}$ for $90 \mathrm{~min}$ with $1 \mathrm{ml}$ of diluted blood (1:4 v/v) obtained by adding freshly prepared PBS at $\mathrm{pH}=7.4$. After incubation, sample-containing blood was centrifuged at $1000 \mathrm{rpm}$ for 5 minutes to separate plasma. The amount of hemoglobin released due to hemolysis was determined spectrophotometrically (absorbance readout at $543 \mathrm{~nm}$ using a Duo spectrophotometer, Beckman). The hemolytic activity was calculated to reference with a negative control consisting of diluted blood without the addition of the samples. Complete hemolysis was induced by the addition of ammonium sulfate $(20 \% \mathrm{w} / \mathrm{v})$. Optical microscopy was used to evaluate changes on red blood cell morphology after incubation with the formulations.

\section{ZIKV titration by plaque assay}

Vero cells, seeded the day before at a density of $6 \times 10^{3}$ in 96 well plates, were inoculated with increasing dilutions of virus prepared in cold MEM with $2 \%$ of FBS. After $2 \mathrm{~h}$ adsorption at $37^{\circ} \mathrm{C}$, the virus inoculum was removed, cells overlaid with $1.2 \%$ methylcellulose and incubated at $37^{\circ} \mathrm{C}$ for $72 \mathrm{~h}$. Plates were then fixed and colored with $0.1 \%$ of crystal violet for 30 minutes and then gently washed with water. The virus titer was estimated as plaque forming units per $\mathrm{ml}(\mathrm{PFU} / \mathrm{ml})$ by counting the number of plaques at an appropriate dilution.

\section{Viability Assay}

Cell viability was measured using the MTS [3-(4,5-dimethylthia-zol-2-yl)-5-(3carboxymethoxyphenyl)-2-(4-sulfophenyl)-2H-tetra-zolium] assay. Vero cells were seeded at a density of $6 \times 10^{3} /$ well in 96 -well plates and treated, the following day, with different concentration 
of $\mathrm{TeW}_{6}, \mathrm{TiW}_{11} \mathrm{Co}$ and $\mathrm{Ti}_{2} \mathrm{PW}_{10}$ compounds under the same experimental conditions described for the ZIKV inhibition assays. Cell viability was determined using the Cell Titer 96 Proliferation Assay Kit (Promega, Madison, WI, USA) according to the manufacturer's instructions. Absorbances were measured using a Microplate Reader (Model680, BIORAD) at $490 \mathrm{~nm}$. The effect on cell viability at different concentrations of the compound was expressed as a percentage, by comparing absorbances of treated cells with those of cells incubated with culture medium alone. The 50\% cytotoxic concentrations $\left(\mathrm{CC}_{50}\right)$ was determined using Prism software (Graph-PadSoftware, San Diego, CA).

\section{ZIKV inhibition assays}

The effect of $\mathrm{TeW}_{6}, \mathrm{TiW}_{11} \mathrm{Co}$ and $\mathrm{Ti}_{2} \mathrm{PW}_{10}$ on ZIKV infection was evaluated by plaque reduction assay. Vero cells were pre-plated $24 \mathrm{~h}$ in advance in 24 -well plates at a density of $7 \times 10^{4}$ cells. The $\mathrm{TeW}_{6}, \mathrm{TiW}_{11} \mathrm{Co}$ and $\mathrm{Ti}_{2} \mathrm{PW}_{10}$ were serially diluted in medium (from $25 \mu \mathrm{M}$ to $0.0016 \mu \mathrm{M}$ ) and added to cell monolayers. After $2 \mathrm{~h}$ of incubation at $37^{\circ} \mathrm{C}$, medium was removed and infection was performed with $250 \mu \mathrm{L} /$ well of MR766 or HPF2013 (MOI $=0.0005$ ) and different concentrations of the POMs, for $2 \mathrm{~h}$ at $37^{\circ} \mathrm{C}$. The virus inoculum was then removed and the cells washed and overlaid with a medium containing $1.2 \%$ methylcellulose (Sigma) and serial dilutions of the POMs. After an incubation at $37^{\circ} \mathrm{C}$ for $72 \mathrm{~h}$, cells were fixed and stained with $0.1 \%$ crystal violet in $20 \%$ ethanol and viral plaques counted. The effective concentration producing $50 \%$ reduction in plaque formation $\left(E_{50}\right)$ was determined using Prism software by comparing treated with untreated wells. The selectivity index $(\mathrm{SI})$ was calculated by dividing the $\mathrm{CC}_{50}$ by the $\mathrm{EC}_{50}$ value.

\section{Rotavirus inhibition assay}

To assess the ability of $\mathrm{TeW}_{6}, \mathrm{TiW}_{11} \mathrm{Co}_{\mathbf{1}}$ and $\mathrm{Ti}_{\mathbf{2}} \mathbf{P W}_{\mathbf{1 0}}$ to inhibit rotavirus infectivity, inhibition assays were carried out with MA104 cells seeded at a density of $1,4 \times 10^{4}$ cells/well in 96 -well plates. Similarly to the ZIKV inhibition assay, cells were pre-treated with serial dilutions of $\mathbf{T e W}_{6}, \mathrm{TiW}_{\mathbf{1 1}} \mathrm{Co}_{\mathbf{0}}$ and $\mathrm{Ti}_{2} \mathbf{P W}_{10}$ (from $25 \mu \mathrm{M}$ to $0.0016 \mu \mathrm{M}$ ) for $2 \mathrm{~h}$ at $37^{\circ} \mathrm{C}$. Then, the medium was removed and the infection was performed with trypsin-activated rotavirus $(\mathrm{MOI}=0.02)$ and different concentrations of the polyoxometalates for $1 \mathrm{~h}$. After incubation, cells were washed with medium and incubated with serial dilutions of POMs for $16 \mathrm{~h}$. Next, cells were fixed with cold acetonemethanol (50:50), and the number of infected cells were determined by indirect immunostaining by using a mouse monoclonal antibody directed to human rotavirus VP6 (0036; Villeurbanne, France), and the secondary antibody peroxidase-conjugated AffiniPure $F\left(a b^{\prime}\right) 2$ Fragment Goat Anti-Mouse IgG $(\mathrm{H}+\mathrm{L}$ ) (Jackson ImmunoResearch Laboratories Inc., 872 W. Baltimore Pike, West Grove, PA 19390). 


\section{ZIKV yield reduction assay}

To test the ability of $\mathrm{Ti}_{2} \mathbf{P W}_{10}$ compound to inhibit multiple cycles of ZIKV replication, Vero cells were seeded at a density of $5 \times 10^{4}$ cells/well in 24 well-plates. The day after, cells were treated and infected in duplicate with a mixture of $\mathrm{Ti}_{2} \mathrm{PW}_{10}(5 \mu \mathrm{M}$ or $15 \mu \mathrm{M})$ and ZIKV (MR766 or HPF2013, $\mathrm{MOI}=0.001$ ) for 2 hours at $37^{\circ} \mathrm{C}$. Following virus adsorption, the virus inoculum was removed and cells were incubated with medium containing the compound ( $5 \mu \mathrm{M}$ or $15 \mu \mathrm{M})$ until control cultures displayed extensive cytopathology. Supernatants were clarified and cell-free virus infectivity titers were determined in duplicate by the plaque assay on Vero cell monolayers.

\section{4. $\mathrm{Ti}_{2} \mathrm{PW}_{10}$ mechanism of action against $\mathrm{ZIKV}$}

\subsection{Virus inactivation assay}

Approximately $10^{5}$ PFU of MR766 or HPF2013 plus EC 90 of $\mathrm{Ti}_{2} \mathrm{PW}_{10}$ were added to MEM and mixed in a total volume of $100 \mu \mathrm{l}$. The virus-compound mixture was incubated for $2 \mathrm{~h}$ at $37^{\circ} \mathrm{C}$ then diluted serially to the non-inhibitory concentration of test compound; the residual viral infectivity was determined by viral plaque assay.

\subsection{Cell pre-treatment assay}

To evaluate the antiviral activity of compound when administered before infection, confluent Vero cells in 24 well plates $\left(7 \times 10^{4}\right.$ cells/well) were pre-treated with different concentrations of $\mathbf{T i}_{2} \mathbf{P W}_{\mathbf{1 0}}$ (from $20 \mu \mathrm{M}$ to $0.08 \mu \mathrm{M}$ ) for 2 hours at $37^{\circ} \mathrm{C}$. After washing, cells were infected with MR766 or HPF2013 at $\mathrm{MOI}=0.0005$ for two hours, then washed and overlaid with $1.2 \%$ methylcellulose medium for $72 \mathrm{~h}$ at $37^{\circ} \mathrm{C}$. At the end of the incubation cells were fixed and stained with $0.1 \%$ crystal violet in $20 \%$ ethanol to count the number of viral plaques.

\subsection{Binding assay}

Vero cells were seeded in 24-well plates at a density of $1.1 \times 10^{5}$. The following day, cells and virus (MR766 or HPF2013 virus, $\mathrm{MOI}=3$ ) were cooled to $4^{\circ} \mathrm{C}$ for 10 minutes and then the virus was allowed to attach to cells on ice in presence of the $\mathbf{T i}_{2} \mathbf{P W}_{\mathbf{1 0}}$ compound (EC $\mathrm{C}_{90}$ ). After an incubation of $2 \mathrm{~h}$ on ice, cells were washed with cold MEM, followed by addition of fresh cold medium. Cells were subjected to three rounds of freeze-thawing to release bound virus and the lysate clarified by low speed centrifugation for 10 minutes. Cell-bound virus titers were determined by viral plaque assay.

\subsection{Entry assay}

For entry assays, MR766 and HPF2013 (MOI=0.005) were adsorbed for $2 \mathrm{~h}$ at $4^{\circ} \mathrm{C}$ on pre-chilled confluent Vero cells in 24-well plates. Cells were then washed twice with cold MEM to remove the unbound virus and then incubated with serial dilutions of $\mathbf{T i}_{2} \mathbf{P} \mathbf{W}_{10}$ compound for $2 \mathrm{~h}$ at a temperature of $37^{\circ} \mathrm{C}$ to allow virus entry. Unpenetrated viruses were inactivated with citrate 
buffer (citric acid $40 \mathrm{mM}$, potassium chloride $10 \mathrm{mM}$, sodium chloride $135 \mathrm{mM}, \mathrm{pH}$ 3) for $1 \mathrm{~min}$ at room temperature, as previously described. ${ }^{4,5}$ Cells were then washed with warm medium 3 times and overlaid with $1.2 \%$ methycellulose medium. After 3 days of incubation, cells were fixed and stained with $0.1 \%$ crystal violet in $20 \%$ ethanol to count the number of viral plaques.

\subsection{Post entry assay: focus reduction assay}

To evaluate the antiviral activity of $\mathbf{T i}_{2} \mathbf{P W}_{10}$ compound when administered after infection, Vero cells were seeded in 96 well-plates at a density of $1,3 \times 10^{4}$ cells/well. The following day, ZIKV (MR766 or HPF2013, MOI=0.01) was allowed to attach to pre-cooled cells for 2 hours at $4^{\circ} \mathrm{C}$. Then, two gentle washes were performed and cells were incubated at $37^{\circ} \mathrm{C}$ for 2 hours to allow virus penetration into the host cell. Unpenetrated viruses were inactivated with citrate buffer for $1 \mathrm{~min}$ at room temperature and cells were subsequently washed with warm medium 3 times and incubated with serial dilutions of $\mathrm{Ti}_{2} \mathrm{PW}_{\mathbf{1 0}}$ (from $20 \mu \mathrm{M}$ to $0.08 \mu \mathrm{M}$ ). After 24 hours cells were fixed with acetone-methanol (50:50). The number of infected cells were determined by indirect immunostaining by using a mouse monoclonal antibody direct to flavivirus protein E (D1-4G2-4-15 (4G2), Novus Biological) and a secondary antibody peroxidase-conjugated AffiniPure F(ab')2 Fragment Goat Anti-Mouse IgG $(\mathrm{H}+\mathrm{L})$ (Jackson ImmunoResearch Laboratories Inc., 872 W. Baltimore Pike, West Grove, PA 19390). Immunostained cells were counted, and the percent inhibition of virus infectivity determined by comparing the number of infected cells in treated wells with the number in untreated control wells.

\subsection{Immunofluorescence experiments}

Subconfluent Vero cell monolayers plated on coverslips in 24-well plates were treated with $\mathrm{Ti}_{2} \mathbf{P W}_{10}\left(E C_{99}\right)$ during the entry of ZIKV into cells or during the post-entry phase. First, the virus (MR766 or HPF2013, MOI=5) was allowed to attach to pre-chilled cells for 2 hours on ice. Subsequently, after the removal of the unbound virus with a gentle wash, the temperature was shifted to $37^{\circ} \mathrm{C}$ in order to allow the virus entry. For the entry assay, the polyanion was added at this time point. After 2 hours of virus adsorption, the unpenetrated virus was inactivated with citrate buffer (as previously described) for $1 \mathrm{~min}$ at room temperature. Three gentle washes were readily performed and fresh medium was added to cells for $30 \mathrm{~h}$. For the post-entry assay, the polyanion was added to cells at this time point (for $30 \mathrm{~h}$ ). Subsequently, cells were washed twice with PBS and fixed in paraformaldehyde $4 \%$ for $15 \mathrm{~min}$ at room temperature. After three washes with PBS, cells were permeabilized with PBS-Triton $0.1 \%$ for 20 min on ice. Cells were then blocked with $5 \%$ BSA for $15 \mathrm{~min}$ and then incubated with the primary antibody (a mouse monoclonal antibody direct to flavivirus protein E (D1-4G2-4-15 (4G2), Novus Biological) diluted in blocking buffer $+0.05 \%$ Tween 20 for $1 \mathrm{~h}$ at room temperature. Three washes in PBS with $0.05 \%$ Tween 20 were subsequently performed followed by an incubation with the secondary antibody (goat anti-mouse IgG rhodamine conjugated, Santa Cruz Biotechnology) diluted in blocking buffer $+0.05 \%$ Tween 20 for $1 \mathrm{~h}$ at room temperature. 
After washing three times with PBS, coverslips were mounted and analysed on a confocal fluorescence microscope (LSM510, Carl Zeiss, Jena, Germany).

\section{Data analysis}

All results are presented as the mean values from three independent experiments performed in duplicate. The $\mathrm{EC}_{50}$ values for inhibition curves were calculated by regression analysis using the software GraphPad Prism version 5.0 (GraphPad Software, San Diego, California, U.S.A.) by fitting a variable slope-sigmoidal dose-response curve.

\section{ESI references:}

1) Ghouzzi VE, Bianchi FT, Molineris I, Mounce BC, Berto GE, Rak M, et al. ZIKA virus elicits P53 activation and genotoxic stress in human neural progenitors similar to mutations involved in severe forms of genetic microcephaly and p53. Cell Death Dis. 2016 Oct;7(10):e2440. doi: 10.1038/cddis.2016.446.

2) Schwarz MC, Sourisseau M, Espino MM, Gray ES, Chambers MT, Tortorella D, et al. Rescue of the 1947 Zika Virus Prototype Strain with a Cytomegalovirus Promoter-Driven cDNA Clone. mSphere. 2016 Oct;1(5). doi:10.1128/mSphere.00246-16

3) Coulson BS, Fowler KJ, Bishop RF, Cotton RG. Neutralizing monoclonal antibodies to human rotavirus and indications of antigenic drift among strains from neonates. J Virol. 1985 Apr;54(1):14-20.

4) Talarico L, Pujol C, Zibetti R, Faria P, Noseda M, Duarte $M$, et al. The antiviral activity of sulfated polysaccharides against dengue virus is dependent on virus serotype and host cell. Antiviral Res. 2005 Jun;66(2-3):103-10. doi:10.1016/i.antiviral.2005.02.001

5) Li C, Deng Y-Q, Wang S, Ma F, Aliyari R, Huang X-Y, et al. 25-Hydroxycholesterol Protects Host against Zika Virus Infection and Its Associated Microcephaly in a Mouse Model. Immunity. 2017 Mar;46(3):446-56. doi:10.1016/j.immuni.2017.02.012 